УДК 94:[(477)+(438)] “20”"

Гулай Василь Васильович

доктор політичних наук, професор,

Національний університет «Львівська політехніка»,

Львів, Україна,

gulayvasyl@gmail.com

\title{
ПОЛІТИКО-КОМУНІКАТИВНИЙ ВИМІР ДИСКУРСУ ПОЛІТИЧНОЇ КОМУНІКАЦІЇ ВІДНОСИН УКРАЇНИ ТА ПОЛЬЩІ НА ПРИКЛАДІ ПОШКОДЖЕННЯ ПОЛЬСЬКИХ ПАМ'ЯТНИКІВ ПОЧАТКУ 2017 р.
}

Політико-комунікативний вимір відносин України та Польщі на сучасному етапі може розглядатися як чільний інструмент їх аналізу та прогнозування актуалізації конфліктогенного потенціалу під впливом зовнішніх та внутрішніх чинників провокативного спрямування. Метою пропонованої роботи $€$ характеристика на засадах міждисциплінарного підходу політикокомунікативного виміру дискурсу політичної провокації відносин України та Польщі на прикладі пошкодження польських пам'ятників на поч. 2017 р. в Гуті Пеняцькій, Львові та Підкамені. У статті сформовано теоретико-методологічні засади дослідження політичної комунікації шляхом систематизації наукового доробку вітчизняних дослідників останнього часу. Узагальнено найвідоміші, 3 точки представлення у мас-медіа, факти пошкодження польських пам'ятників на Львівщині в січні-березні 2017 р. Обгрунтовано мотиви політичної провокації українсько-польських відносин через пошкодження польських пам'ятників зовнішньою стороною - Російською Федерацією, яка використовує весь арсенал інформаційно-психологічної зброї для розпалювання «війни пам'ятників».

Ключові слова: українсько-польські відносини, політична комунікація, політична провокація, пам'ятники.

Hulai Vasyl, Doctor of Political Sciences, Professor, "Lviv Polytechnic" National University, Lviv, Ukraine

Political and communicative dimension of the political communication discourse on Ukrainian-Polish relations on the sample of the early 2017 polish monuments damage

Nowadays political and communicative dimension of the Ukrainian-Polish relations is to be studied as a leading tool of the conflict potential actualization analysis and prediction, influenced by external and internal provocation aim factors. The purpose of the proposed work is, using a cross-disciplinary approach, to give characteristics of the political and communicative dimension of the Ukrainian-Polish 
relations political provocations discourse with an early 2017 damaged polish monuments in Huta Penyatska, Lviv and Pidkamin being the very sample.The article sums theoretical and methodological foundations of the political communication researches through systemation of the scientific domestic works of nowadays. The article generalizes well-known facts about January -March, 2017 Lviv region polish monuments damage in terms of the media representation. It also provides us with the ground on the Ukrainian and Poland relations political provocations motives through damaging polish monuments by the outer side, particularly the Russian Federation, the latter addressing to the whole arsenal of the information and psychological weapons to unleash the "war of monuments".

Key words: Ukrainian-Polish relations, political communication, political provocation, monuments.

Гулай Василий Васильевич, доктор политических наук, профессор, Национальный университет «Львовская политехника», Львов, Украина

Политико-коммуникативное измерение дискурса политической коммуникации отношений Украины и Польши на примере повреждения польских памятников начала 2017 г.

Политико-коммуникативное измерение отношений Украины и Польши на современном этапе может рассматриваться как главный инструмент их анализа и прогнозирования актуализации конфликтогенного потенциала под влиянием внешних и внутренних факторов провокационного толка. Целью предлагаемой работы является характеристика на основе междисциплинарного подхода политико-коммуникативного измерения дискурса политической провокации отношений Украины и Польши на примере повреждения польских памятников в нач. 2017 г. в Гуте Пеняцкой, Львове и Подкамне. В статье сформированы теоретико-методологические основы исследования политической коммуникации путем систематизации научного наследия отечественных исследователей последнего времени. Обобщены известные, с точки представления в СМИ, факты повреждения польских памятников на Львовщине в январе-марте 2017 г. Обоснованы мотивы политической провокации украинопольских отношений из-за повреждения польских памятников внешней стороной - Российской Федерацией, которая использует весь арсенал информационно-психологического оружия для разжигания «войны памятников».

Ключевые слова: украино-польские отношения, политическая коммуникация, политическая провокация, памятники. 
Вступ. Пропонована тема статті може вважатися актуальною як у теоретичному, так й прикладному вимірах, дозволяючи на міждисциплінарній методологічній базі розглянути потенційно конфліктогенні аспекти новітнього етапу українсько-польських відносин крізь призму зовнішньої провокації 3 використанням маніпулятивно-пропагандистських інструментів представлення політичних подій в інформаційно-комунікаційному просторі.

Аналіз останніх досліджень і публікацій. Теоретико-методологічну базу дослідження політичної комунікації в Україні на сучасному етапі складають роботи О. Анісімович-Шевчук [1], О. Буданової [3], С. Денисюк [8] та ін. У комунікативно-прикладному аспекті варто окремо згадати доробок М. Павлюх [11]. Основну емпіричної бази пропонованого дослідження становлять публікації відомих українських інтернет-ресурсів, які вийшли за межі регіонального контенту, зокрема «Галінформ», «Експрес», «ЗІК», «Захід.нет» та ін.

Вітчизняною політичною наукою достатньо повно розкриті політикокультурні підвалини та інституційно-процедурні засади активного розвитку політичної комунікації в України останнього десятиліття. Одночасно не можемо не вказати на відсутність прикладних політико-комунікативних досліджень актуального стану українсько-польських відносин.

Формулювання мети та завдань статті. Метою даної роботи $є$ аналіз політико-комунікативного виміру дискурсу політичної провокації відносин України та Польщі поч. 2017 р. Відповідно до поставленої мети необхідно вирішити наступні дослідницькі завдання: сформувати теоретико-методологічні засади дослідження політичної комунікації; узагальнити факти пошкодження польських пам'ятників на Львівщині останніх місяців; обгрунтувати мотиви політичної провокації українсько-польських відносин через пошкодження польських пам'ятників на поч. 2017 р.; вказати на зовнішню сторону політичної провокації відносин України та Польщі на сучасному етапі інструментами «війни пам'ятників».

Виклад основного матеріалу дослідження. Структуроутворювальнич елементом політичного життя суспільства, що пов'язує воєдино різні частини суспільства і дозволяє їм функціонувати, $є$ політична комунікація, яка е процесі передачі емоційного та інтелектуального змісту в одних випадках орієнтується на формування суспільної думки (чи ії зміну) внаслідок аргументації на користь (чи проти) колективних форм діяльності [1, с. 7].

Політичну комунікацію визначено як засіб інформаційної взаємодії політичних акторів та суспільства через двосторонній обмін політичною інформацією, рfснований на соціокультурних засадах, що дозволяє досягти 
політичної узгодженості та взаєморозуміння у процесі політичної діяльності й сформувати на цій основі збалансовану соціально-політичну систему [1, с. 7].

До структури політичної комунікації С. Денисюк включає (інформаційний, матеріальний, людський, символьний тощо, які доповнюються психологічними компонентами (емоції, стереотипи, страхи), політичною поведінкою та політичною діяльністю (відображають ефективність політичної комунікації) і політичними технологіями компоненти: та виділяє такі основні iï форми: раціональну і спонтанну; формальну і неформальну; горизонтальну i вертикальну; безпосередню, опосередковану і квазівзаємодію; комунікацію в ході виборів, референдумів, демонстрацій тощо [8, с. 11].

Нині формується нова структура політичної комунікації: політичні інтернет-комуніканти, канали і технічні засоби інформування та здійснення зворотного зв'язку [7, с. 1].

Передумовами виникнення політичної інтернет-комунікації стали трансформації моделей комунікації під впливом процесів інформатизації та розвитку інформаційно-комунікаційних технологій. Політичну інтернеткомунікацію запропоновано розглядати як систему цілеспрямованих та послідовних дій щодо вироблення політичної інформації, яка відображається в певній текстовій, графічній або звуковій формах, щодо ії поширення у мережі Інтернет $з$ використанням сукупності технічних засобів, які забезпечують іï циркуляцію (передавання, обмін, споживання тощо) 3 метою відтворення політичної взаємодії відповідно до інтересів політичних акторів, суспільства та індивідів [3, с. 9].

Політики формують політичну ситуацію через політичні рішення, події, повідомлення, звернення у медіа. Медіа через опінієтворчу функцію формують політичну активність, політичну свідомість, політичну соціалізацію громадян. Медіа створюють загальне уявлення про політичну ситуацію, владу та політиків. Політики звертаються до медіа, щоб поширити звернення чи ін. політичну інформацію для ознайомлення широкої аудиторії [11, с. 13].

Цілком очевидно, що таке може носити й очевидний провокативний вектор маніпулятивного впливу на відповідну аудиторію. Під політичною провокацією розуміється діяльність, що усвідомлено здійснюється одним суб'єктом 3 метою спонукання іншого до таких політичних дій, які матимуть негативні наслідки для провокованого та/або позитивні, для провокатора [12, c. 234].

Соціально-політична комунікація в сучасних польських медіа об'єднує декілька базових понять, важливих у іiі формуванні: проблемно-тематичний контент сучасних польських видань (українсько-польська комунікація, українсько-польські відносини, епістолярна журналістика та історична думка 
про Волинь 1943 р., українська національна ідея, стереотипи України у польській пресі), політична культура польських ЗМІ (політична реклама/телереклама), а також превентивність польської преси (філософія політичної культури), аксіологічний напрям польської журналістики у висвітленні проблем державотворення, євроінтеграційні процеси Польщі та України $[11$, с. 1$]$.

Зросла соціальна активність та соціальна самоорганізація значної частини українського суспільства (як офлайн, так і онлайн), відбувається зміна моделі політико-комунікативної взаємодії акторів та об'єктів політичного процесу, з'являються принципово нові форми політичної активності тощо [3, c. 1].

Одночасно, в політико-комунікативному просторі присутні елементи політичних провокацій. Спрямованість провокації $є$ двоякою. Відкрита і водночас опосередкована іiі мета - порушення прав та інтересів іншого суб'єкта. Латентна і кінцева мета провокації - стимулювати спровокованих на неадекватну відповідь та, як наслідок, - компрометувати себе, знизити підтримку політичних ідей та цінностей, які відстоюють спровоковані [12, c. 234].

Сумний початок провокації українсько-польських відносин було дано 8 січня 2017 р., коли невідомі сплюндрували пам'ятник убитим за часів Другої світової війни цивільним мешканцям польського поселення Гута Пеняцька на Бродівщині Львівської області. Бічні стели були розмальовані стилізованим нацистським символом «SS», а викарбувані імена загиблих поляків зафарбували синьо-жовтими та червоно-чорними барвами. Центральний монумент-хрест розбили на кавалки [9].

Вперше інформація про знищення пам'ятника у Гуті Пеняцькій з'явилася ще вранці 9 січня у антиукраїнських групах ВКонтакте. Тобто майже за добу до того, як почалося розслідування цієї справи і про цей випадок дізналися більшість українських ЗМІ. Втім, о 13:45 інформація про цей випадок 3'являється на фейсбук-сторінці колишнього телеведучого «Інтера» і ведучого «Антимайдану» Юрія Кота. Він також не додав фото $з$ місця події, написавши лише, що на пам'ятнику написали «Слава Україні». Допис створений задовго до публікації перших новин на цю тему і набрав вже більшого резонансу. Зокрема, пост Юрія Кота поширили сторінка Жовківської районної організації «Партії регіонів» і послідовники Віктора Медведчука. Окрім них цей допис скопіювали й кілька користувачів ВКонтакте. Уже 3 посиланням на російський Regnum інформація про знищений пам'ятник пішла на інші сайти. Одним 3 перших українських агентств цю новину о 20:51 дав «Корреспондент», що входить медіа 
холдингу UMH, який досі належить скандальному бізнесмену-втікачу Сергієві Курченку [14].

У цьому зв'язку, Радник глави МЗС Польщі, професор Пшемислав Журавський вел Граєвський вважає, що за пошкодженням польського пам'ятника у Гуті Пеняцькій стоїть Москва. Експерт звернув увагу, що відео, розміщене в YouTube, підписано українською мовою з русизмами. Він нагадав, що упродовж 2015-2016 рр. при знищенні українських пам'ятників у Польщі вандали так само залишали там польські написи 3 помилками. «Нцидент стався 8 січня - у другий день Різдва в Україні. Це ще більше підкреслює нереальність того, що українець, галичанин, у день великого свята піде нищити пам'ятник. У психологічному сенсі це виглядає гротескно», - підкреслив радник глави польського зовнішньополітичного відомства. За його словами, знищення пам'ятника у Гуті Пеняцькій є свідченням того, що «триває інтенсивна спроба посварити народи нашого регіону, яким загрожує Росія». Журавський вел Граєвський наголосив, що на цей інцидент обидві сторони повинні відреагувати солідарно, наголошуючи, що поляки й українці не дозволять себе посварити [13].

Навіть відома польська дослідниця Ева Семашко, яка дотримується переконання, що українські повстанці вчинили геноцид поляків у часи Другої світової війни, заявила, що до руйнування меморіалу в Гуті Пеняцькій причетні російські провокатори [4].

Екс-лідер «Правого сектору», а нині командувач «Української добровольчої армії» Дмитро Ярош назвав руйнування пам'ятника «гидкою провокацію російських спецслужб»та закликав усіх жити сьогоденням i майбутнім «спираючись не на ненависть і шовінізм, а на спільні християнські цінності, спільну, часто героїчну історію (протиставлення османській навалі, походи на Москву, битви з ордами Будьонного і Тухачевського, спільні бої підрозділів Української Повстанської Армії та Армії Крайової проти більшовиків тощо)» [4].

Пам'ятний знак в Гуті Пеняцькій було повністю відновлено вже через місяць після інциденту. Жалобні урочистості відбулися на місці трагедії напередодні 73 роковин - 26 лютого 2017 р. [17].

Не інакше як провокативна може бути оцінена поведінка керівника служби ВО «Свобода» 3 питань національної пам'яті Михайла Галущака, який 26 лютого, під час відкриття відновленого меморіалу в Гуті Пеняцькій, розгорнув банер з фотографіями зруйнованих українських пам'ятників у Польщі та червоно-чорний прапор [10]. У розмові з кореспондентом Захід.нет він розповів, що під час відкриття відновленого меморіалу у Гуті Пеняцькій він один стояв з банером, до нього ніхто не приєднався. Він також додав, що 
приїхати на відкриття вирішив сам і не радився з колегами ВО «Свобода» [5], проте автор не може погодитися 3 такими поясненнями, передовсім 3 огляду на специфічну форму партійної дисципліни у «Свободі» та ставлення іiі ін. керівників до українсько-польських відносин періоду Другої світової війни.

10 березня 2017 p. у Львові на Вулецьких пагорбах вандали «помалювали» пам'ятник польським професорам, яких нацисти розстріляли тут у 1941 р. Вандали закидали червоною фарбою і написали «смерть ляхам» на задній частині експозиції. Адміністрація відреагувала швидко і добре, відразу видалила всі написи з монумента [16].

12 березня 2017 р. стало відомо про чергову провокацію із польськими пам'ятниками. У селі Підкамінь на Львівщині невідомі розмалювали червоною фарбою пам'ятники жертвам польсько-українського конфлікту. На центральному хресті з'явився напис «Смерть ляхам!» і свастика [6].

Упродовж 2014-2016 pp. у Польщі невідомі вандали зруйнували i осквернили 14 могил i пам'ятних знаків українцям. Донині жоден не відновлений. Польська сторона зволікає з цим питанням [6]. У жодному 3 випадків вандалів не було затримано. Проте інформація про випадки руйнувань дуже часто першою з'являлася в російських 3МI, що дає підстави стверджувати, що ці акти вандалізму координуються з Росії [15].

У Польщі, як і в Україні, політична еліта й експертне середовище добре усвідомлюють, хто стоїть за польсько-українською «війною» 3 пам'ятниками, але суспільство бачить фото, формує відповідні асоціації і вимагає від політиків негайну реакцію й адекватні відповіді. Однак, саме на поспіх й емоції розраховують виконавці злочинів, а ще більше - їхні замовники - очевидно, що з Москви [2].

Як відповідь на вказані акти вандалізму, 15 березня 2017 р. у Варшаві глави МЗС України i Польщі Павло Клімкін i Вітольд Ващиковський домовилися спільно боротися 3 актами вандалізму або актам політичної провокації у місцях пам'яті [15].

Висновки та перспективи подальших досліджень. Отже, на основі проведеного політико-комунікативного дослідження можна обгрунтовано вказати на зовнішню сторону політичної провокації відносин України та Польщі на сучасному етапі інструментами - Російську Федерацію. У цьому зв'язку безвідповідальними видаються дії окремих представників правих політичних середовищ обох країн, які, якщо й не прямо долучені до реалізації російської стратегії й тактики гібридної війни проти України та Польщі, але й не можуть не усвідомлювати своєї ролі в актуалізації конфліктогенного потенціалу українсько-польських відносин, передовсім 3 огляду на історичний досвід взаємних кривд, образ та збройної боротьби. Одночасно, адекватно реагуючи на 
провокацію Російською Федерацію українсько-польської «війни пам'ятників», відповідальні наукові, експертні та політичні кола повинні шукати та пропагувати історію та сьогодення спільної боротьби українського та польського народу проти реалізації російських реваншистських планів новітніми методами інформаційно-психологічної війни в Інтернет-просторі. Перспективним напрямом наукових розвідок може стати аналіз висвітлення проблематики відносин України та Польщі в реаліях новітніх викликів й загроз провідними українськими мас-медіа.

\section{Список використаних джерел:}

1. Анісімович-Шевчук О. 3. Політична комунікація як системоутворюючий фактор політичного життя суспільства: автореф. дис. ... канд. політ. наук: спец. 23.00.02 «Політичні інститути та процеси» / Анісімович-Шевчук О. 3. ; Львів. нац. ун-т ім. І. Франка. - Львів, 2010. - 19 с.

2. Банахевич Ю. Україна-Польща: на порозі охолодження відносин? [Електронний ресурс] / Ю. Банахевич. - Режим доступу: https://www.ukrinform.ua/rubric-abroad/2171484-ukrainapolsa-na-porozioholodzenna-vidnosin.html. - Назва з екрану. - Дата звернення: 08.02.2017.

3. Буданова О. Б. Політична комунікація в інтернет-просторі:український контекст: автореф. дис... канд. соціолог. наук: спец. 22.00 .04 «Спеціальні та галузеві соціології» / Буданова О.Б.; Харків. нац. ун-т ім. В. Н. Каразіна. Харків, 2015. - $18 \mathrm{c}$.

4. Вандалізм у Гуті Пеняцькій [Електронний ресурс]: реакція в Україні та Польщі. - Режим доступу: http://www.istpravda.com.ua/short/2017/01/12/149447/. - Назва з екрану. - Дата звернення: 01.12.2017.

5. Вербовська М. На урочистостях у Гуті Пеняцькій поліція затримала «свободівця» з провокативним баннером [Електронний ресурс] / М. Вербовська. - Режим доступу: http://zaxid.net/news/showNews.do?na_urochistostyah_u_guti_penyatskiy_politsiya_z atrimala_svobodivtsya_z_provokativnim_banerom\&objectId=1419077/. - Назва 3 екрану. - Дата звернення: 26.02.2017.

6. Війна пам'ятників триває. Тепер у Підкамені [Електронний ресурс]. Режим доступу: http://www.istpravda.com.ua/short/2017/03/12/149604/. - Назва 3 екрану. - Дата звернення: 12.03.2017.

7. Готун А. М. Нові інформаційно-комунікаційні технології в глобальній системі політичної комунікації: автореф. дис. ... канд. політ. наук: спец. 23.00.04 «Політичні проблеми міжнародних систем та глобального розвитку» / Готун А. М. ; Ін-т світової екон. і міжнар. відносин НАН України. - Київ, 2010. $17 \mathrm{c}$. 
8. Денисюк С. Г. Політична комунікація: ціннісні основи та механізми реалізації в умовах сучасного суспільного розвитку: автореф. дис... д-ра політ. наук: спец. 23.00.03 «Політична культура та ідеологія» / Денисюк С. Г. ; Нац. пед. ун-т ім. М. П. Драгоманова. - Київ, 2013. - 36 с.

9. На Львівщині осквернили два меморіали загиблим полякам [Електронний pecypc]. http://zik.ua/news/2017/03/12/u_seli_pidkamin_na_lvivshchyni_znovu_oskvernyly_m ogyly_polyakiv_ffoto_1058819/. - Назва з екрану. - Дата звернення: 13.03. 2017.

10. На урочистостях у Гуті Пеняцькій поліція затримала «свободівця» 3 провокативним банером [Електронний ресурс]. - Режим доступу: http://lviv.web2ua.com/na-urochistostjah-u-guti-penjackij-policija-zatrimalasvobodivcja-z-provokativnim-banerom-7459/. - Назва з екрану. - Дата звернення: 27.02.2017.

11. Павлюх М. В. Соціально-політична комунікація в сучасних польських медіа: автореф. дис... канд. наук: спец. 27.00.04 «Теорія та історія журналістики» / Павлюх М. В. ; Львів. нац. ун-т ім. І. Франка. - Львів, 2016. $20 \mathrm{c}$.

12. Петренко Б. М. Політична провокація та політичний екстремізмі в теорії і практиці суспільних відносин / Б. М. Петренко // Філософія і політологія в контексті сучасної культури. - 2012. - Вип. 3. - С. 232-239.

13. Російські провокатори викрили себе датою зруйнування меморіалу в Гуті Пеняцькій - радник глави МЗС Польщі [Електронний ресурс]. - Режим доступу: http://expres.ua/news/2017/01/11/222382-rosiyski-provokatory-vykrylysebe-datoyu-zruynuvannya-memorialu-guti/. - Назва з екрану. - Дата звернення: 27.02.2017.

14. Тузяк Н. Хто приготував провокацію у Гуті Пеняцькій [Електронний ресурс ] / Н. Тузяк. http://zaxid.net/news/showNews.do?hto_prigotuvav_provokatsiyu_u_guti_penyatskiy \&objectId=1414635 / Н. Тузяк. - Назва з екрану. - Дата звернення: 11.01.2017.

15. Україна і Польща домовилися спільно боротися 3 руйнуванням пам'ятників [Електронний ресурс]. - Режим доступу: https://www.ukrinform.ua/rubric-politycs/2193810-ukraina-i-polsa-domovilisa-spilnoborotisa-z-rujnuvannam-pamatnikiv.html. - Назва 3 екрану. - Дата звернення: 15.03.2017.

16. У Львові вандали «розписали» пам'ятник загиблим професорам [Електронний ресурс]. http://galinfo.com.ua/news/u_lvovi_vandaly_pomalyuvaly_pamyatnyk_zagyblym_pol skym_profesoram_254430.html. - Назва з екрану. - Дата звернення: 12.03.2017. 
17. Odnowionopomnik w HuciePieniackiej [Zasób elektroniczny]. - Tryb dostępu: http://kuriergalicyjski.com/actualnosci/polska/5697-odnowiono-pomnik-whucie-pieniackiej-wideo. - Last access: 24.02.2017. - Title from the screen.

\section{References:}

1. Anisimovych-Shevchuk, O.Z. (2010). Political communication as a systemforming factor in the political life of society. D.Ed.: Lviv Ivan Franko National University.

2. Banakhevych, Yu. (2017). Ukraine-Poland: on the brink of cooling relations? [online] Available at: https://www.ukrinform.ua/rubric-abroad/2171484ukrainapolsa-na-porozi-oholodzenna-vidnosin.html. [Accessed 08 February 2017]. Title from the screen.

3. Budanova, O.B. (2015). Political Communication in the Internet Space: Ukrainian Context. D.Ed. Kharkiv National University named after V.N. Karazin.

4. Vandalism in Guta Pienyatskaya. Reaction in Ukraine and Poland. (2017). Ukrainska pravda [Ukrainian truth] [online] Available at: http://www.istpravda.com.ua/short/2017/01/12/149447/. [Accessed 01 December 2017]. Title from the screen.

5. Verbovska, M. (2017). At the festivities in Guta, Peniatsky police detained $a$ "freedomist" with a provocative banner [online] Available at: http://zaxid.net/news/showNews.do?na_urochistostyah_u_guti_penyatskiy_politsiya_z atrimala_svobodivtsya_z_provokativnim_banerom\&objectId=1419077. [Accessed 26 February 2017]. Title from the screen.

6. The war of monuments continues. Now in Pidkamin. (2017). Ukrainska pravda [Ukrainian truth]. [online] Available at: http://www.istpravda.com.ua/short/2017/03/12/149604. [Accessed 12 March 2017]. Title from the screen.

7. Hotun, A.M. (2010). New information and communication technologies in the global system of political communication. D.Ed. Institute of World Economy and International Relations of the National Academy of Sciences of Ukraine.

8. Denysiuk, S.H. (2013). Political communication: value bases and mechanisms of realization in the conditions of modern social development. G.D.Ed. National Pedagogical University named after M. P. Drahomanov.

9. Two memorials to the dead Polish were desecreted in Lviv oblast. (2017). [online] Available http://zik.ua/news/2017/03/12/u_seli_pidkamin_na_lvivshchyni_znovu_oskvernyly_m ogyly_polyakiv__foto_1058819. [Accessed 13 March 2017]. Title from the screen.

10. At the festivities in Guta, Peniatsky police detained a "freedomist" with a provocative banner. (2017). [online] Availiable at: http://lviv.web2ua.com/na- 
urochistostjah-u-guti-penjackij-policija-zatrimala-svobodivcja-z-provokativnimbanerom-7459. [Accessed 27 February 2017]. Title from the screen.

11. Pavliukh, M.V. (2016). Social and political communication in contemporary Polish media. D.Ed. Lviv Ivan Franko National University.

12. Petrenko, B.M. (2012). Political provocation and political extremism in the theory and practice of social relations. Filosofiia $i$ politolohiia $v$ konteksti suchasnoi kultury [Philosophy and political science in the context of modern culture], issue 3, pp. 232-239.

13. Russian provocateurs discovered the date of the demolition of the memorial in Guta Penyatskaya - Polish Foreign Minister advisor. (2017). [online] Available at: http://expres.ua/news/2017/01/11/222382-rosiyski-provokatory-vykrylysebe-datoyu-zruynuvannya-memorialu-guti. [Accessed 27 February 2017]. Title from the screen.

14. Tuziak, N. (2017). Who prepared a provocation in Guth Peniyatskaya [online] Available at: http://zaxid.net/news/showNews.do?hto_prigotuvav_provokatsiyu_u_guti_penyatskiy \&objectId=1414635. [Accessed 11 January 2017]. Title from the screen.

15. Ukraine and Poland agreed to fight together the destruction of monuments. (2017). [online] Available at: https://www.ukrinform.ua/rubricpolitycs/2193810-ukraina-i-polsa-domovilisa-spilno-borotisa-z-rujnuvannampamatnikiv.html. [Accessed 15 March 2017]. Title from the screen.

16. In Lviv, the vandals "painted" a monument to the dead professors. (2017). [online] Availiable at: http://galinfo.com.ua/news/u_lvovi_vandaly_pomalyuvaly_pamyatnyk_zagyblym_pol skym_profesoram_254430.html. [Accessed 12 March 2017]. Title from the screen.

17. Odnowionopomnik w HuciePieniackiej. (2017). [online] Available at: http://kuriergalicyjski.com/actualnosci/polska/5697-odnowiono-pomnik-w-huciepieniackiej-wideo. [Accessed 24 February 2017]. Title from the screen.

(C) Гулай В. В., 2018 